\title{
PENGARUH PENGGUNAAN ABU CANGKANG SAWIT DARI BOILER TERHADAP SIFAT FISIK ETERNIT
}

\section{(THE INFLUENCE OF THE USE ASH PALM OIL SHELL FROM BOILER ON THE PHYSICAL PROPERTIES OF PLASTERBOARD)}

\author{
Haspiadi $^{1}$ \& Eko Heryadi ${ }^{2}$ \\ ${ }^{1}$ Balai Riset dan Standardisasi Industri Samarinda \\ ${ }^{2}$ Fakultas Teknik Universitas Mulawarman \\ 1e-mail: haspiadi k@yahoo.com \\ ²e-mail : e.heryadi@ft.unmul.ac.id
}

Naskah diterima tanggal 23 Januari 2013, disetujui tanggal 23 April 2013

\begin{abstract}
ABSTRAK
Pembakaran cangkang sawit sebagai bahan bakar pada boiler menghasilkan abu sebesar $15 \%$ yang memiliki kandungan silika ( $\mathrm{SiO} 2$ ) cukup tinggi yaitu sebesar $68,82 \%$ dan alumina $\left(\mathrm{Al}_{2} \mathrm{O}_{3}\right)$ sebesar $3,08 \%$. Silika dan alumina adalah senyawa yang diperlukan dalam campuran pembuatan berbagai macam bahan bangunan salah satunya adalah eternit. Tujuan dari penelitian ini adalah mengkaji potensi abu cangkang sawit sebagai salah satu bahan dasar pembuatan eternit dengan menganalisa sifat fisik yang terbentuk. Abu cangkang sawit dicampur dengan semen, kapur dan serat dengan komposisi abu cangkang sawit 20\%, 40\%, 60\%, $80 \%$ dan $0 \%$ sebagai kontrol. Eternit dicetak menggunakan alat konvensional sederhana. Dari hasil pengujian eternit sesuai metode uji pada SNI 15 0233-1989 tentang Lembar Serat Semen diperoleh komposisi terbaik penggunaan abu adalah $60 \%, 20 \%$ kapur dan $15 \%$ semen serta $5 \%$ serat. Hasil uji menunjukkan bentuk dan kekuatan paku baik, warna putih alami, kerapatan air tidak terjadi tetesan air serta penyerapan air rendah $29,3 \%$ dan bobot isi yang kecil $7,7 \mathrm{~g} / \mathrm{cm}^{3}$.
\end{abstract}

Kata Kunci : Eternit, abu cangkang sawit, kapur, sifat fisik

\section{ABSTRACT}

Shell burning oil as a fuel in the boiler produces ash by $15 \%$ which contains silica (SiO2) is quite high at $68.82 \%$ and alumina $\left(\mathrm{Al}_{2} \mathrm{O}_{3}\right)$ of $3.08 \%$. Silica and alumina are required compounds in the mixture making various kinds of buildings materials one of which is plasterboard. The purpose of this study is to asesess the potential of oil shell ash a raw material in the manufacture of plasterboard formed to analyze the physical properties. Ash from palm oil shell is along with bonding cement, lime and fiber. The component of plasterboard is $20 \%, 40 \%, 60 \%$ and $80 \%$, also $0 \%$ as a control. The plasterboard making was done by using some simple equipment. The best result of analysis according to examination method for fiber cements sheets in SNI 15 0233-1989 is obtained the maximum composition is 60\% ash, 20\% lime, $15 \%$ cement and $5 \%$ fiber. At this composition has a good shape, good nail strength, white natural color, the density of water is not happening dropping water and low the water absorption $=29,3 \%$ and also low weight of content $=7,7 \mathrm{~g} / \mathrm{cm}^{3}$.

Key words : Plasterboard, ash of palm nut shell, lime, physical properties 


\section{PENDAHULUAN}

$\mathrm{P}$ roses pengolahan buah kelapa sawit untuk menghasilkan minyak dilakukan dengan cara ekstraksi. Selain menghasilkan minyak sawit kotor (CPO) juga hasil samping berupa serat, cangkang, dan tandan buah kosong. Saat ini serat dan cangkang banyak digunakan sebagai bahan bakar boiler untuk produksi uap (steam). Cangkang sawit sendiri memiliki nilai kalor tertinggi yaitu 20,093 $\mathrm{KJ} / \mathrm{Kg}$ dibandingkan TKKS $18.795 \mathrm{KJ} / \mathrm{Kg}$, serat $19.055 \mathrm{KJ} / \mathrm{Kg}$, dan batang pohon sawit $17.471 \mathrm{KJ} / \mathrm{Kg}$ (Goenadi, dkk. 2005).

Hasil limbah pembakaran cangkang sawit sebagai bahan bakar pada boiler adalah $85 \%$ limbah agregat (agregat halus, sedang dan kasar) sebagai bottom ash, dan $15 \%$ abu halus atau fly ash (Febijanto, 2011). Data lain menyebutkan bahwa produksi abu cangkang sawit dari boiler sisa proses pembakaran mencapai $5 \%$. (Haspiadi data tidak dipublikasi).

Karakteristik dan komposisi abu sisa pembakaran cangkang pada boiler mengandung $61 \%$ silika $\left(\mathrm{SiO}_{2}\right), 1,5 \%$ kalsium (CaO), 7,5 \% kalium $\left(\mathrm{K}_{2} \mathrm{O}\right), 2,8 \%$ magnesium (MgO) serta berat jenis 0,33 $\mathrm{g} / \mathrm{cm}^{3}$ (Zahrina. 2007). Komposisi dan kandungan bahan yang terdapat dalam abu cangkang sawit sesuai dengan senyawa yang dibutuhkan dalam proses pembuatan eternit.

Tujuan dari penelitian ini adalah mengkaji sifat fisik eternit yang dibuat dengan bahan substitusi abu sisa pembakaran cangkang sawit.

\section{METODE PENELITIAN}

Penelitian dilakukan di Laboratorium Balai Riset dan Standardisasi Industri Samarinda. Abu cangkang sawit yang digunakan diperoleh dari PT. Waru di Kabupaten Penajam Pasir Utara Propinsi Kalimantan Timur.

\section{Metode}

\section{Penyiapan Abu}

Abu cangkang sawit dipisahkan dari kotoran yang masih ada, kemudian dihaluskan dan diayak menggunakan ayakan $850 \mu \mathrm{m}$. Abu yang lolos ayakan sebelum digunakan dianalisa kandungan kimianya, meliputi $\mathrm{SiO}_{2}$, alumina $\left(\mathrm{Al}_{2} \mathrm{O}_{3}\right)$, besi $\left(\mathrm{Fe}_{2} \mathrm{O}_{3}\right)$ calcium $(\mathrm{Ca})$ dan magnesit $(\mathrm{MgO})$ serta berat jenis dengan merujuk pada SNI 15-0233-1989 tentang Lembaran Serat Semen, Mutu dan Cara Uji, karena acuan untuk cara uji dan syarat mutu eternit belum diterbitkan.

Komposisi campuran pembuatan bahan eternit dilakukan melalui 15 perlakuan berupa perbandingan antara persen abu cangkang sawit, Kpur, semen dan serat sebagaimana tersaji pada Tabel 1.

Masing-masing formula perlakuan diaduk secara homogen dalam keadaan kering untuk kemudian dicampur dengan air sedikit demi sedikit hingga terbentuk pasta (kira-kira kadar air berapa). Pasta yang terbentuk dituang ke dalam cetakan sambil diratakan menggunakan sendok semen dan dibiarkan hingga kering dan secara perlahan dikeluarkan dari cetakan dan dilanjutkan pengeringan di atas rak-rak pengering yang terbuat dari kayu sebagaimana tersaji Gambar 1.

\section{Bahan}


Tabel 1. Komposisi Campuran Bahan-bahan Pembuatan Eternit

\begin{tabular}{cccc}
\hline Abu Cangkang Sawit (\%) & Kapur (\%) & Semen (\%) & Serat (\%) \\
\hline $0 \%$ & 90 & 5 & 5 \\
$0 \%$ & 85 & 10 & 5 \\
$0 \%$ & 80 & 15 & 5 \\
$20 \%$ & 70 & 5 & 5 \\
$20 \%$ & 65 & 10 & 5 \\
$20 \%$ & 60 & 15 & 5 \\
$40 \%$ & 50 & 5 & 5 \\
$40 \%$ & 45 & 10 & 5 \\
$40 \%$ & 40 & 15 & 5 \\
$60 \%$ & 30 & 5 & 5 \\
$60 \%$ & 25 & 10 & 5 \\
$60 \%$ & 20 & 15 & 5 \\
$80 \%$ & 10 & 5 & 5 \\
$80 \%$ & 5 & 10 & 5 \\
$80 \%$ & 0 & 15 & 5 \\
\hline
\end{tabular}

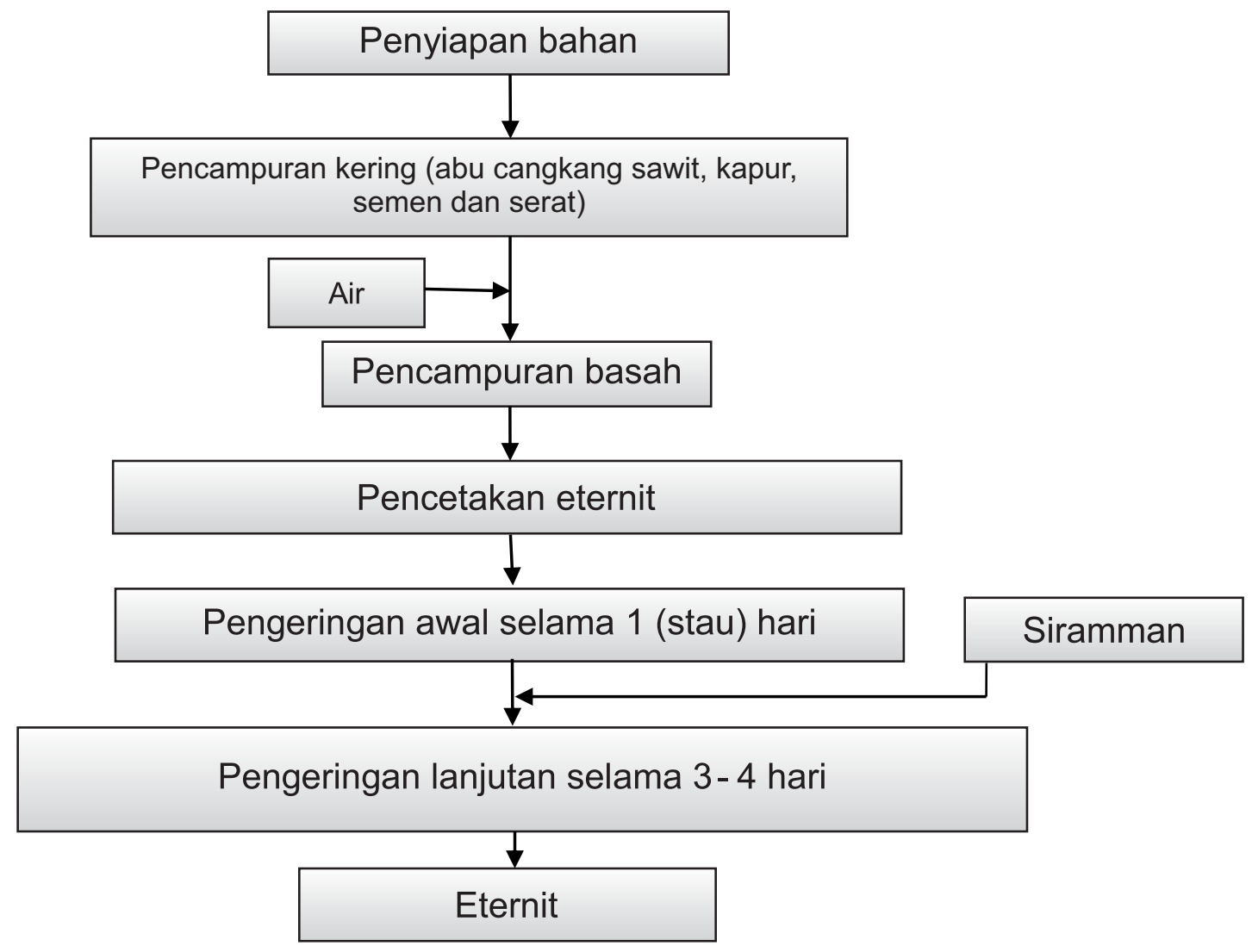

Gambar 1. Diagram Alir Pembuatan Eternit

\section{Pengujian}

Uji sifat fisik eternity mencakup kerapatan air, kemampuan dipaku, penyerapan air dan bobot isi eternit serta pengamatan terhadap bentuk/ pandangan luar dan warna dengan mengacu pada SNI 15-0233-1989 
tentang Lembaran Serat Semen, Mutu dan Cara Uji. Hal ini dilakukan mengingat acuan untuk cara uji dan syarat mutu eternit belum dirumuskan dalam SNI. Sedangkan untuk syarat mutu membandingkan dengan kontrol.

\section{HASIL DAN PEMBAHASAN}

Hasil uji bahan baku abu cangkang sawit yang digunakan berturut-turut adalah silika $\left(\mathrm{SiO}_{2}\right) 68,82 \%$ adb; alumina $\left(\mathrm{Al}_{2} \mathrm{O}_{3}\right)$ $3,08 \%$ adb; besi $\left(\mathrm{Fe}_{2} \mathrm{O}_{3}\right) \quad 3,47 \%$ adb; clkalcium (Ca) 6,95\% adb dan magnesit (MgO) 4,35 \% adb. Secara keseluruhan sampai pada tingkat $60 \%$ penggunaan abu cangkang sawit menunjukkan produk yang baik. Namun hasil terbaik diperoleh pada komposisi $60 \%$ abu cangkang sawit, $20 \%$ kapur, 15\% semen dan $5 \%$ serat Tabel 2 .

Tabel 2. Hasil Uji Sifat Fisik Eternit

\begin{tabular}{|c|c|c|c|c|c|c|c|}
\hline \multicolumn{2}{|c|}{$\begin{array}{l}\text { Bahan Utama Eternit } \\
\text { (A) }\end{array}$} & \multirow{2}{*}{$\begin{array}{c}\text { Semen } \\
(\%)\end{array}$} & \multirow{2}{*}{$\begin{array}{c}\text { Serat } \\
(\%)\end{array}$} & \multirow[b]{2}{*}{ Bentuk } & \multirow{2}{*}{$\begin{array}{l}\text { Pandangan } \\
\text { Luar (warna) }\end{array}$} & \multirow{2}{*}{$\begin{array}{c}\text { Kerapatan } \\
\text { Air }\end{array}$} & \multirow{2}{*}{$\begin{array}{c}\text { Kemampu } \\
\text { an dipaku } \\
\text { Eternit }\end{array}$} \\
\hline $\begin{array}{c}\text { Abu } \\
\text { Cangkang } \\
\text { Sawit (\%) }\end{array}$ & $\begin{array}{c}\text { Kapur } \\
(\%)\end{array}$ & & & & & & \\
\hline $0 \%$ & 90 & 5 & 5 & Baik & Alami putih & $<30 \%$ (,Rapat air) & Baik \\
\hline $0 \%$ & 85 & 10 & 5 & Baik & Alami putih & $<30 \%$ (,Rapat air) & Baik \\
\hline $0 \%$ & 80 & 15 & 5 & Baik & Alami putih & $<30 \%$ (,Rapat air) & Baik \\
\hline $20 \%$ & 70 & 5 & 5 & Baik & Alami putih & $<30 \%$ (,Rapat air) & Baik \\
\hline $20 \%$ & 65 & 10 & 5 & Baik & Alami putih & $<30 \%$ (,Rapat air) & Baik \\
\hline $20 \%$ & 60 & 15 & 5 & Baik & Alami putih & $<30 \%$ (,Rapat air) & Baik \\
\hline $40 \%$ & 50 & 5 & 5 & Baik & Alami putih & $<30 \%$ (,Rapat air) & Baik \\
\hline $40 \%$ & 45 & 10 & 5 & Baik & Alami putih & $<30 \%$ (,Rapat air) & Baik \\
\hline $40 \%$ & 40 & 15 & 5 & Baik & Alami putih & $<30 \%$ (,Rapat air) & Baik \\
\hline $60 \%$ & 30 & 5 & 5 & Baik & Alami putih & $<30 \%$ (,Rapat air) & Baik \\
\hline $60 \%$ & 25 & 10 & 5 & Baik & Alami putih & $<30 \%$ (,Rapat air) & Baik \\
\hline $60 \%$ & 20 & 15 & 5 & Baik & Alami putih & $>30 \%$ (Tidak rapat air) & Baik \\
\hline $80 \%$ & 10 & 5 & 5 & $\begin{array}{l}\text { Tidak } \\
\text { diamati }\end{array}$ & $\begin{array}{l}\text { Putih } \\
\text { kehitaman }\end{array}$ & $>30 \%$ (Tidak rapat air) & Baik \\
\hline $80 \%$ & 5 & 10 & 5 & $\begin{array}{l}\text { Tidak } \\
\text { diamati }\end{array}$ & Tdk diuji & Tdk diuji & Tdk diuji \\
\hline $80 \%$ & 0 & 15 & 5 & $\begin{array}{l}\text { Tidak } \\
\text { diamati }\end{array}$ & Tdk diuji & Tdk diuji & Tdk diuji \\
\hline
\end{tabular}

Bentuk

Secara umum bentuk keseluruhan eternit yang dihasilkan dari hasil pengamatan tidak terdapat retak, kerutan atau cacat lain yang dapat mempengaruhi pemakaiannya. Kecuali untuk campuran $80 \%$ limbah abu cangkang dari pengamatan yang dilakukan ditemukan retakan dan cacat, sehingga pengamatan untuk pandangan luar tidak dilanjutkan.

Kondisi seperti ini dapat disebabkan berat jenis abu yang ringan $\left(0,16 \mathrm{~g} / \mathrm{cm}^{3}\right)$ dibandingkan dengan hanya penggunaan kapur dengan berat jenis yang lebih tinggi yaitu berkisar 2,6-2,8 g/ $\mathrm{cm}^{3}$ (Salain., dkk. 2009) dengan berat jenis sehingga berpengaruh terhadap proses pencampuran dan pada saat kering mudah retak. Sedangkan pengamatan pandangan luar yang baik dimana tidak terdapat retak, kerutan atau cacat lain pada eternit diperoleh dari penggunaan $20 \%$ sampai dengan $60 \%$ pengunaan abu cangkang sawit. Hal ini dapat disebabkan oleh unsur silika dalam abu cangkang sawit bila bereaksi dengan kapur membentuk kalsium silikat yang mempunyai sifat penyemenan (Riyadi dkk, 2005). Selain itu pula permukaan yang baik dapat disebabkan kandungan $\mathrm{MgO}$ dalam abu boiler yang cukup tinggi sebesar $4,35 \%$. Sebagaimana fungsi $\mathrm{MgO}$ dalam proses pembuatan semen memiliki pengaruh 
terhadap penampakan dan permukaan yang licin (Anonimous, 2000).

\section{Pandangan luar (Warna) Eternit}

Pengamatan warna secara visual dilakukan untuk mengetahui aspek estetika bila menggunakan campuran abu cangkang serta aplikasi penggunaan cat atau pewarna saat digunakan. Adapun hasil pengamatan tersaji pada Tabel 2 .

Pengamatan warna eternit secara visual terlihat bahwa eternit yang dihasilkan berwarna putih alami pada komposisi bahan campuran maksimum $60 \%$ abu cangkang sawit dari boiler : $20 \%$ kapur dan $15 \%$ penggunaan semen serta $5 \%$ serat.

Sedangkan untuk komposisi abu yang semakin tinggi yaitu $80 \%$ abu cangkang dari boiler, $10 \%$ kapur dan 5\% semen, warna dari eternit menjadi putih sedikit kehitaman, sehingga untuk penggunaan $80 \%$ abu cangkang sawit dari boiler: $5 \%$, kapur $10 \%$ dan $5 \%$ serat tidak dilanjutkan pengamatan warna.

Sifat warna eternit sangat dipengaruhi oleh jenis bahan yang digunakan. Bila diamati dari setiap perlakuan untuk eternit yang menggunakan bahan kapur dominan warna terlihat alami putih namun semakin banyak abu cangkang dari boiler yang digunakan kecenderungan warna menjadi kehitaman yang dipengaruhi oleh warna abu cangkang dari boiler sedikit hitam akibat sisa karbon yang tidak terabukan sempurna.

\section{Kerapatan Air}

Hasil pengujian kerapatan air yang melewati pori-pori eternit secara umum menunjukkan rapat air atau tidak terjadi rembesan pada saat dilakukan pengujian selama 5 x 24 jam dan dinyatakan rapat air bila dari sejumlah benda uji yang diuji terdapat paling banyak $30 \%$ saja yang bocor.

Pengamatan pada perlakuan $60 \%$ abu cangkang sawit dari boiler, $25 \%$ kapur dan $10 \%$ semen serta $5 \%$ serat persentase rembesan yang diukur dari luasan permukaan yang mengalami rembesan $<30 \%$ demikian pula dengan penggunaan kapur 0\%, 20\% dan 40\%. Sedangkan penggunaan $60 \%$ abu cangkang dari boiler, $20 \%$ dan semen $15 \%$ serta $5 \%$ serat hasil penelitian menunjukkan tidak rapat air yang diindikasikan lebih dari $30 \%$ permukaan bagian bawah bocor atau adanya rembesan setelah $5 \times 24$ jam pengamatan.

Demikian pula dengan penggunaan abu cangkang dari boiler $80 \%$ dengan kapur $10 \%$ dan $0 \%$, sehingga untuk parameter kerapatan air formula yang terbaik adalah penggunaan abu $60 \%, 25 \%$ kapur dan $10 \%$ semen dan $5 \%$ serat sebagaimana pada Tabel 2.

Namun bila dilihat secara umum dari perlakuan $20 \%$ sampai dengan $60 \%$ penggunaan abu cangkang dari boiler menunjukkan bahwa porositas eternit sudah baik dan dapat diaplikasilkan pada penggunaan eternit yang tidak menimbulkan rembesan bila terkena tetesan atau tumpahan air dalam waktu $5 \mathrm{x}$ 24 jam secara terus-menerus sesuai syarat mutu SNI 15-0233-1989 butir 3 bentuk dan pandangan luar lembaran serat semen. Dari komposisi bahan semakin banyak penggunaan abu cangkang sawit kecenderungan sifat eternit tidak rapat air, yang dapat dimungkinkan oleh berat jenis abu yang ringan sehingga menyebabkan pembentukan pori.

\section{Kemampuan Dipaku}

Uji kemampuan paku dilakukan untuk mengetahui efek atau pengaruh terhadap kekompakan bahan eternit saat dipaku, yang dilakukan pada bidang yang rata dan dipaku pada bagian tepinya dengan jarak $1,5 \mathrm{~cm}$ memakai paku berdiameter $1 \mathrm{~mm}$. Jarak antara lubang paku yang satu dengan lainnya adalah $15 \mathrm{~cm}$. Hasil uji yang dinyatakan baik jika tidak lebih $20 \%$ proses pemakuan menimbulkan cacat atau retak sesuai syarat mutu SNI 15-02331989 butir 3 bentuk dan pandangan luar lembaran serat semen.

Hasil uji kemampuan paku seperti tersaji pada Tabel 2, umumnya kemampuan untuk dipaku baik. Sifat ini terjadi untuk semua perlakuan sama dengan kontrol, baik $20 \%, 40 \%, 60 \%$ dan $80 \%$, kecuali penggunaan $80 \%$ abu cangkang sawit dari boiler berbanding $5 \%$ 
dan $0 \%$ kapur serta $10 \%$ dan $15 \%$ semen tidak diuji karena sifat eternit saat pencetakan menimbulkan cacat pada saat proses pemakuan,. Sifat kemampuan dipaku dapat disebabkan eternit memiliki kerapatan yang baik dan kematangan bahan (semen) yang sempurna sehingga tidak mudah hancur.

Selain itu pula abu cangkang kelapa sawit yang digunakan mengandung unsur silika (SiO2) cukup tinggi sebesar $68,82 \%$. Jika ditambahkan dalam campuran pembuatan eternit, maka unsur silika tersebut akan bereaksi dengan kapur bebas $\mathrm{Ca}(\mathrm{OH})_{2}$ yang merupakan unsur lemah akan menjadi gel baru. Gel ini merupakan unsur utama yang mempengaruhi kekuatan pasta semen, dan meningkatkan kuat lekat atau kekompakan bahan (Anonimous, 1998).

Hasil uji ini menunjukkan bahwa eternit yang dihasilkan dapat diaplikasikan pada pemakaian untuk rumah tangga yang membutuhkan pemasangan menggunakan paku.

\section{Penyerapan Air Eternit}



Gambar 2. Hasil uji penyerapan air

Penyerapan air yang diuji untuk perlakuan $20 \%$, 40\%, $60 \%$ dan $80 \%$ abu cangkang sawit dari boiler rata-rata berkisar $26,3 \%$ sampai dengan $32,0 \%$, sedikit lebih tinggi dari sifat penyerapan air untuk campuran tanpa penggunaan abu sebagai kontrol $(0 \%$ abu) yaitu berkisar $24,7 \%$ sampai dengan $26,0 \%$ yang menggunakan jumlah kapur $90 \%, 85 \%$ dan $80 \%$ serta $5 \%, 10 \%$ dan $15 \%$ semen, Tinggi-rendahnya sifat penyerapan air dapat disebabkan oleh tingkat kejenuhan dari bahan itu sendiri dan besarnya porositas dari bahan yang dapat menyimpan air dalam beberapa saat. Nilai penyerapan air ini mempengaruhi tingkat kerapatan eternit sebagaimana dijelaskan oleh Yuniarti. Dkk 2011 bahwa penyerapan air yang rendah akan menghasilkan kerapatan yang tinggi.

\section{Bobot Isi Eternit}

Hasil uji bobot isi eternit berbanding terbalik dengan penggunaan abu cangkang sawit dari boiler. Penggunaan abu 20\% berbanding $70 \%, 65 \%, 60 \%$ kapur serta semen

$5 \%, 10 \%$ dan $15 \%$, kemudian abu $40 \%$ berbanding $50 \%, 45 \%, 40 \%$ kapur serta semen $5 \%, 10 \%$ dan $15 \%$, dan abu $60 \%$ berbanding $30 \%, 25 \%, 20 \%$ kapur serta semen $5 \%, 10 \%$ dan $15 \%$ serta dengan

abu $80 \%$ berbanding $10 \%$ kapur serta semen $5 \%$ menurun atau semakin kecil bobot isinya Gambar 3.

Penurunan ini dapat disebabkan bobot jenis abu cangkang yang sangat kecil yaitu



$0,16 \mathrm{~g} / \mathrm{cm}^{3}$ sehingga berpengaruh terhadap bobot akhir eternit. Sebaliknya semakin sedikit penggunaan abu dan semakin banyak penggunaan kapur dan semen yang memiliki bobot jenis lebih besar, bobot jenis eternit juga akan semakin besar.

\section{KESIMPULAN}

Berdasarkan hasil pecobaan dapat disimpulkan bahwa abu cangkang sawit dapat dimanfaatkan sebagai bahan 
pembuatan eternit. Hasil uji sifat fisik eternit yaitu bentuk, pandangan luar, dan kemampuan dipaku serta kerapatan air dan bobot jenis bila dibandingkan dengan kontrol, komposisi bahan yang terbaik adalah penggunaan $60 \%$ abu cangkang sawit, $20 \%$ kapur, $15 \%$ semen dan $5 \%$ serat. Namun untuk penyerapan air dari semua komposisi yang dilakukan dalam percobaan masih lebih tinggi dari kontrol.

\section{DAFTAR PUSTAKA}

Anonimous, 1998. Proses Industri Kimia I Materi Pelajaran PEDC Bandung, Edisi 1998

Anonimous, 2000. Coal Bottom Ash/ Boiler Slag-Material Description. Tersedia di : http://www.cedar.at/mailarchives/ waste/abahsi.htm. Diakses pada tanggal 17 Mei 2008.

BSN, 1989. Standard Nasional Indonesia (SNI) 15-0233-1989. Cara Uji dan Syarat Mutu Lembaran Serat Semen

Febijanto I. 2011. Kajian Teknis \& Keekonomian Pembangkit Listrik Tenaga Biomassa Sawit; Kasus: Di Pabrik Kelapa Sawit Pinang Tinggi, Sei Bahar, Jambi. Jurnal of Mechatronics, Electrical Power and Vehicular Technology. Volume 02, No. 1 pp 11-22, 2011, Terbit online: 7
Juli 2011. PTPSE, BPPT, Jakarta 2011.

Goenadi, D.H, Wayan R. S dan Isroi. 2005. Pemanfaatan Produk Samping Kelapa Sawit Sebagai Sumber Energi Alternatif Terbarukan. Badan Litbang Pertanian. Jakarta.

Yuniarti. K, Jeff Hann, and Ismail Budiman, 2011. Assesing the Influence of Initial Moisture Content and Density on Rubinate Uptake by Microwave-Dried Sitka Spruce Wood.

Lacrosse, L. (2004). Clean and Efficient Biomass Cogeneration Technology in ASEAN, COGEN 3 Seminar on " Business Prospects in Southeast Asia for European Cogeneration Equipment", 23 November 2004, Krakow, Poland.

Riyadi M dan Amalia., 2005. Teknologi Bahan. Jurusan Teknik Sipil., Politeknik Negeri Jakarta.

Salain I.M, Ardana M.D dan Tahriri W. Pengaruh Asam KArbonat $\left(\mathrm{HCO}_{3}\right)$ Terhadap Kekuatan Tumbukan Agregat Batu Kapur. Jurnal IImiah Teknik Sipil Vol. 13, No. 2, Juli 2009.

Zahrina. I, 2007. Pemanfaatan Abu Sabut dan Cangkang Sawit Sebagai Sumber Silika pada Sintesis ZSM-5 dari Zeolit Alam, Jurnal Sains dan Teknologi 6(2) September 2-7: 3134. Fakultas Teknik Universitas Riau. 